\title{
Compensation Management And Employee Retention of Selected Commercial Banks In Anambra State, Nigeria.
}

\author{
Obianuju Mary Chiekezie \\ Faculty of Management Sciences, Nnamdi Azikiwe University, Awka, Nigeria. \\ Gerald Emejulu \\ Faculty of Management Sciences, Nnamdi Azikiwe University, Awka, Nigeria.

\section{Aniekwe Nwanneka} \\ Faculty of Management Sciences, Nnamdi Azikiwe University, Awka, Nigeria.
}

\begin{abstract}
This study was necessitated due to rate of employee turnover, which is increasing in Nigeria banking system; a situation whereby employee continuously move from one bank to another in a short period of time. This paper seeks to examine the influence of compensation management on employee retention. It specifically set out to examine the relationship between Salary and Employee satisfaction in selected Commercial banks in Awka. The study employed descriptive research design. Primary source of data was the major instrument used for this study. 60 copies of questionnaire were administered to employees of selected commercial banks (First bank, Fidelity and Sterling bank); 56 were retrieved and they were all useful. Pearson's Product Moment Correlation was used for the analyses. The findings revealed that there is a positive weak relationship between salary and employee satisfaction. This shows that employees were not satisfied despite their seemingly attractive salary. In view of the finding, the study concluded that if management fail to formulate, administer and implement a good compensation policies that would allow them retain their talented employee; these employee might leave their job if they find a better offer elsewhere. The researcher recommended among others that compensation structure should include new and enticing ways to motivate and retain employee with wide range of benefits other than salary.
\end{abstract}

Keywords: Compensation, Employee Retention, Salary, Employee Satisfaction, Commercial Banks, Nigeria

\section{INTRODUCTION}

Employees are the organisations key resource and the success or failure of organisations centre on the ability of the employers to attract, retain and reward appropriately talented and competent employee. Employee's willingness to stay on the job largely depends on compensation packages of the organisation (Armstrong, 2003). In attempt to ensure employee optimal satisfaction and retention, organisations need to consider a variety of appropriate ways to reward the employee to get the desired result (Falola, 2014). It has been argued that the degree to which employee are satisfied with their job and their readiness to remain in an organisation is a function of compensation packages (Osibanjo, 2012).

Organisations that have goals to achieve would require satisfied and happy staff in her workforce. Importantly is the fact that for any bank to take off and achieve its strategic goals would strongly depend on her capacity to attract, retain and maintain competent and satisfied staff into its employment (Oshagbemi, 2000). 
One of the fundamental tasks in Human Resources Management is Compensation Management. It is a complex task that occurs periodically, demand accuracy and must not be delayed. Compensation Management requires integrating employees' processes and information with business process and strategies to achieve optimal organisational goals and objectives. This can be attributed to the fact that Compensation Management is an essential tool to "integrate individual efforts with strategic business objectives by encouraging employees to do the right things with ever improving efficiency" (Horwitz, 2010). In other words, compensation management is a powerful means of focusing attention within an organisation. They send clear messages to all employees of the, organisation informing them about expected attitudes and behaviours (Smith, 1992). For the workers, wage provides the means of satisfying their wants and needs. Compensation packages entails some basic features that tend to make employee satisfy on their job amongst which include salaries, bonuses, incentives etc and these have significant impact on employee satisfaction (Idemobi, Onyeizugbe, and Akpunonu, 2011). Compensation Management and Employee Retention as Independent variable can be influenced by these variables.

This study focus on the influence of Compensation Management on Employee Retention in Banking Industry. The study is deemed necessary because of the disturbing high rate of employee turnover in banking industries in Nigeria. Nigeria banks could be categorised according to their assets value; the Large, Medium and Small size banks (Financial Results, 2013). First bank, Fidelity bank and Sterling bank respectively were selected to represent each category for this study.

First Bank of Nigeria PLC (First Bank) is Nigeria's largest financial services institution by total assets and gross earnings. With more than 10 million customer accounts, First Bank has over 750 branches providing a comprehensive range of retail and corporate financial services. The Bank has been named "The Best Bank Brand in Nigeria" four times in a row - 2011, 2012, 2013, 2014 - by the globally renowned "The Banker Magazine" of the Financial Times Group; and "Most Innovative Bank in Africa" in the EMEA Finance African Banking Awards 2014 (www.firstbankinigeria.com/about-us)

Fidelity Bank Plc began operations in 1988 as Fidelity Union Merchant Bank Limited. By 1990, it had distinguished itself as the fastest growing merchant bank in the country. It converted to a commercial bank in 1999, following the issuance of a commercial banking license by the Central Bank of Nigeria, the national banking regulator. That same year the bank rebranded to Fidelity Bank Plc. Fidelity Bank is today ranked amongst the top 10 in the Nigerian banking industry, with presence in all the 36 States as well as major cities and commercial centers of Nigeria. (www.fidelitybankinigeriaplc.com/about-us)

Sterling Bank Plc originally incorporated in 1960 as Nigeria Acceptances Limited (NAL). Consequent to the indigenization decree of 1972, the Bank became fully government owned and was managed in partnership with Grindlays Bank Limited. In January 2006, as part of the consolidation of the Nigerian banking industry, NAL Bank completed a merger with four other Nigerian Banks namely Magnum Trust Bank, NBM Bank, Trust Bank of Africa and Indo-Nigeria Merchant Bank (INMB) and adopted the Sterling Bank name. The merged entities were successfully integrated and have operated as a consolidated group ever since. (www.sterlingbankinigeria.com)

There had been a constant mobility of skilled and unskilled staff from one bank to another. The skilled persons critically hardly stay for long in one bank before moving to another bank 
and this mobility has been tagged as "Brain Drain". This will amount to high cost of Recruitment and Training to the banks which in short run will affect the productivity of the banks. This study therefore attempts to examine the influence of compensation management on employee retention.

\section{Statement of the Problem}

The rate at which employee turnover is increasing in banking sector in Anambra State and Nigeria Generally has become a thing of concern and it is obvious that the step taken by the managements have not solved this problem. The evolving target in banking industry in Nigeria evident from Merger and acquisition has called for good formulation, administration and implementation of good compensation policies that would allow these banks to retain their best hands. There had been constant mobility of these highly skilled employees from one bank to another and they hardly stay for long in one bank before moving to another bank.

In view of the above, one of the reasons that informed this study has to do with the unique importance of salary in relation to employee satisfaction among bankers in bank industries. This affects the retention of employee yet it is not being addressed. There is need therefore, to find out and examine the relationship between salary and employee satisfaction among banker. This is necessary to identify how best to retain these bankers (at least for a longer period of time) to prevent constant mobility.

\section{Objectives of the Study}

The broad objective is to examine the influence of Compensation Management on Employee Retention. The specific objective is:

i. To examine the significant relationship that exists between salary and employee satisfaction.

ii. The Compensation Management was decomposed as Salary while Employee Satisfaction was used to decompose Employee Retention

\section{Research Questions}

The following research question was formulated to address the research objective;

i. To what extent does salary influence employee satisfaction?

\section{Research Hypothesis}

$\mathbf{H}_{1}$ : There is a significant relationship between salary and employee satisfaction.

\section{Conceptual Review \\ Employee Retention}

REVIEW OF RELATED LITERATURE

Employee retention refers to policies and practices companies use to prevent valuable employees from leaving their job. It involves taking measures to encourage employees to remain in the organisation for the maximum period of time. Hiring knowledgeable people for the job is essential for an employer; but retention is even more important than hiring. Previous research has identified several factors that have an influence on employee retention. A first important indicator of employee retention is their organisational commitment (Curtis \& Wright 2001).

Employees with a high organisational commitment are those who have a strong identification with the organisation, value the sense of membership within it. This commitment is influenced by the organisation's norms and practices, especially the organisational climate (Kaliprasad 2006), and is not job specific (Bashaw\& Grant 1994). Jyothi and Venkatesh (2006) suggest the 
following aspects while attempting to retain employees: planning ahead, clarity in job requirements, identify a good source of recruitment, screening and interview, provide challenging work, and focus on compensation and working conditions.

Walker (2001) identified seven factors that can enhance employee retention: (i) compensation and appreciation of the performed work, (ii) provision of challenging work, (iii) chances to be promoted and to learn, (iv) invitational atmosphere within the organisation, (v) positive relations with colleagues, (vi) a healthy balance between the professional and personal life, and (viii) good communications. Together, these suggest a set of workplace norms and practices that might be taken as inviting employee engagement. Hytter (2007) found that the personal premises of loyalty, trust, commitment, and identification and attachment with the organisation have a direct influence on employee retention. She also demonstrated that workplace factors such as rewards, leadership style, career opportunities, the training and development of skills, physical working conditions, and the balance between professional and personal life have an indirect influence (Hytter 2007). Newstrom (2009) states excessive employee turnover can have several negative effects on an organisation. They include:

- Separation costs (exit interview time, separation pay, unemployment and tax increase)

- Training costs for few new employees (both orientation and skill development instruction; both formal and informal learning experiences)

- Vacancy costs (temporary help or overtime pay; productivity loss and service disruption)

- Placement costs (attracting, screening, and relocating new hires)

- Morale effects (loss of friendship, concerns about personal job loss during downsizing)

\section{Compensation Management}

Compensation is a crucial instrument for the attraction and retention of talented employees that are dedicated to their responsibilities within the firm. Compensation management aims to promote the achievement of business goals through attracting, motivating and retaining hard working employees (Shieh 2008; Petera 2011). Compensation management is a crucial component of the overall management of an organisation. It refers to the process by which employees are remunerated for their input at the workplace (Khan 2011).

Employee compensation refers to all the returns that accrue to employees arising from their employment (Dessler 2008; Van Der Merwe 2009; Nazim-ud-Din 2013). Compensation management requires accuracy and precision as, if not adequately and objectively dealt with, it may hamper organisation's operations. Compensation is not only in the form of money, but also in non-cash form. Benefits, such as pension, life and health insurance, and retirement plans, and allowances that include company cars or subsidized transportation, represent a significant pay element in many large firms. In addition, for tax advantages and economies of scale of purchasing that make it economically advantageous for the firm to provide those element, the compensation are always viewed benefits as a tools for attracting and retaining desired employees. Maslow brought in the need hierarchy for the rights of the employees. He stated that employees do not work only for money but there are other needs too which they want to satisfy from their job, i.e. social needs, psychological needs, safety needs, selfactualization, etc. (Octavious, 2015)

Researchers are of the view that firms that seek to improve employees' productivity should link remuneration and personal effort (Encinosa III, Gaynor, Rebitzer. 2007; Kaplan and Norton 2007; Bartlett and Ghosal 2013). Heneman (1992) argues that rewards and bonuses for 
personal effort are the most visible ways of acknowledging an employee's efforts. However, programs that reward effort cannot be compared with new administrative procedures based on uninterrupted progress, joint effort and support (Demming 1986; Snell and Dean 1994; Lepak and Snell 2002). Firms are beginning to give greater recognition to individual pay and performance not only to encourage increased productivity and efficiency, but also to retain highly valued to achieve the firm's objectives (Kuvaas 2006). Lee and Bruvold (2003) note, that the more encouragement employees receive, the higher their level of commitment to the firm. Gardner (2004) concurs with this point of view. Similarly, Lawler (2003) argues that when remuneration is linked to effort, both individual and organisational performance is enhanced. Lawler (2003) added that tying remuneration to performance improves employee motivation, as workers become more results-oriented. Employees will make more effort to achieve results when they are aware that their remuneration package is determined by their contribution to the firm's performance (Lawler 2003).

\section{Types of Compensation}

There are various forms of compensation and nearly all these forms of compensation can be categorised into four broad types (Alsabri\& Ramesh, 2012). The four broad types are:

(a) Wages and Salary: Wages are what is paid to employees who are not permanently employed and typically pertains to hourly rates of pay (the more hours worked, the greater the pay), while salary is what is paid to people that are permanently employed and this is at a fixed weekly, monthly, or annual rate of pay.

(b) Incentive Plans: This is an additional compensation which is above and beyond the employees wage or salary provided. It may be long term or short term in nature.

(c) Employee Benefit Programmes: Time off with pay, pension scheme, tuition reimbursement, recreation activities, cafeteria services are all examples of employee benefit programmes.

(d) Additional Privileges: Employees in organisations may have other privileges such as the usage of company vehicles/cars, club membership or travelling allowance. These privileges may be a substantial part of compensation, especially for the executives. DeCenzo and Robbins (2007) and Khan (2011) explored compensation/reward management and they submitted that rewards are of three major types which are as follows:

- Intrinsic and Extrinsic Rewards: Intrinsic rewards are self-generated rewards whish are anchored on self-contentment arising from the job itself and this often referred to as intangible rewards such as being part of a team, ego as a result of achieving a goal and self-importance and satisfaction arising from one's own work/effort. While extrinsic rewards are emoluments provided by the superiors such as salary increment, bonus, sales commission etc. and this is also referred to as the tangible rewards.

- Financial and Non-financial Rewards: Financial rewards are the rewards received by employees in monetary forms and this assists the employees to boost the financial and social status. But non-financial rewards is made up of inexpensive rewards to heighten the employees morale like long service award, best employee of the year etc.

- Performance-based and membership-based Rewards: Firms equally offer rewards to its employees based on their membership in that organisation or on the basis of accomplishing high performance.

\section{Salary}

Salary is a huge motivator for many employees. Making the connection between money and performance motivates employees to be more productive and to go the extra mile (Zingheim 
and Schuster, 2007). Salary is what is paid to people that are permanently employed and this is at a fixed weekly, monthly, or annual rate of pay.It is an agreed payment given at regular intervals in exchange for work done. Caring about employees on a personal level is important as well. Those employees who do work well to support the company may not receive much salary for their efforts so employers that choose to under-pay their employee know that these employees will work hard for minimal pay, and these employers will pay them accordingly (Zingheim and Schuster, 2007). At the same time, the same employers will pay more to other employees who are not willing to work for minimal compensation. This salary disparity leads to dissatisfaction because eventually the hard worker will notice that he or she is not being paid fairly for the amount of work they are doing, and will begin searching for another company that will appreciate his or her labour.

\section{Employee Satisfaction}

Employee satisfaction is defined as the result of a psychological comparison process of the extent to which various aspects of their pay (e.g. salaries, benefits and incentives) measure up to what they desire (Batol, 1992). Thus, the larger the gap between what employees have and what they want from their jobs, the less satisfied they are; (employees tend to be most satisfied with their jobs when what they are expecting matches with what they actually collect. An employee' overall satisfaction is the cumulative result of comparisons that she makes between what her job provides and what she desires in various areas. The fact that perceived importance makes such a big difference in how employees feel also has implications for management. Obisi, (2003), listed factors that contribute to employee satisfaction as; adequate salary, good working conditions, job security, regular promotion, recognition, etc.

\section{Theoretical Framework}

This study is anchored on Equity theory propounded by Stacey J. Adams. The theory suggests that employee perceptions of what they contribute to the organisation, what they get in return, and how their return-contribution ratio compares to others inside and outside the organisation,' determine how fair they perceive their employment relationship to be (Adams, 1963). Perceptions of inequity are expected to cause employees to take actions to restore equity. According to this theory, employees who see themselves as being under-rewarded will experience distress. The theory, primarily, focuses on ensuring that the distribution of compensation and benefits is fair to all members.

The theory is disposed to the present study in the sense that Pay inequality affects employee satisfaction because pay is positively associated with the job satisfaction of the employees. Employees feel satisfied or dissatisfied with their pay - not so much by the total amount received, but by comparing their benefits with those enjoyed by others in the same field.

\section{Empirical Review}

Terera (2014), carried out research on impact of reward on job satisfaction and employee retention among nurses in Easter Cape Province of South Africa. His study utilised a quantitative research design and 180 nurses were randomly selected; he observed that employee rewards lead to employee retention but however, they do not result in job satisfaction.

Lauri, Morgan, Dave, and Michael (2014) conducted a study on the tenuous relationship between salary and satisfaction in University of Michigan, United State of America (USA). The study revisited the classic notions of satisfaction of employee within organisation using online survey targeted to a sample of working adults which consisted of 79 participants, consisting of 
$60 \%$ male and $40 \%$ female with individual annual gross salary and household gross salary. Using hierarchical multiple regression analysis to test their hypotheses, their finding pit salary in a negative relationship to both job and life satisfaction.

Okpara (2004) carried out study on the impact of salary differential on managerial job satisfaction. The study was on Gender gap and its implication for management education and practice in Nigeria banking sector. A number of 340 bank managers who were member of Chartered Institute of Bankers of Nigeria (CIBN) were chosen for the investigation. The result show that there was a significant gap in salary between Male and female bank manager and that female bank managers were less satisfied with their salary than their male counterparts. The study suggests that management break "the glass ceiling" by paying both sexes comparable salaries for comparable work responsibilities; this would increase satisfaction and performance and also help to retain the best qualified employee.

Mwakidim and Obwogi (2015) examined the effect of pay and work environment on employee retention in Hotel industry in Mombasa. Their findings revealed that pay had a weak influence on employee retention while work environment has a strongest influence. They recommended that employers in the industry need to re-evaluate the current weaknesses associated with pay.

Adeoye and Ziska (2014) carried out research on compensation management and employee job satisfaction in Nigeria's Insurance Sector. 212 respondents were used and the statistical analysis revealed that compensation management and employee job satisfaction are significantly correlated though weak.

Mensah Ruby (2012) employed a survey method in finding out the impact of indirect compensation on employee productivity in Central University College (CUC) of Ghana. There were 280 responses for the survey. Questionnaire administration and condition of service manual of CUC were used to measure the relationship between variables. The study uncovered that though management implements some of the indirect compensation available, there are other benefits which are not satisfactorily administer and this has contributed to a lack of zeal towards work, which has affected the productivity negatively. The study recommends that management of CUC should provide the necessary attention that indirect compensation deserves, as this will help boast the moral of employee which will result in higher productivity. Benita and Anghelache's (2012) study on teachers' motivation and pay found no difference between male and female teachers in terms of overall payment. They posited that job satisfaction derives from adequate and continuous payment by a strong desire for achievement and affiliation. Likewise, Azash (2012) study on job characteristics as determinants of work motivation and job satisfaction revealed that skills, task identity, task significance and feedback serve as either positive or negative predictors of employee job satisfaction.

Latif (2011) examined job satisfaction among public and private college teachers, focusing on the factors that contribute to job satisfaction and dissatisfaction. Findings of the stugy show that college teachers in the public sector reported higher levels of job satisfaction than their private sector counterparts.

\section{SUMMARY OF LITERATURES REVIEWED}

Many of the relevant Literature reviewed on Compensation Management and Employee retention were carried out outside Nigeria like (Sharon, 2014 in Eastern Cape Province of South Africa, Lauri et al, 2014 in USA, Mwakidim et al, 2015 in Mombasa, Mensah, 2012 in Ghana). Though Adeoye et al, 2014 carried out their study in Nigeria but in Insurance sector; Okpara, 2004 attempted carrying out his study in banking industry but narrowed it to gender 
gap. Great results were achieved in those studies, however, this study intends to ascertain the influence of salary on employee satisfaction in Nigeria banking industry with particular reference to selected Commercial banks in Awka metropolis.

\section{Research Design}

\section{METHODOLOGY}

This study adopted a descriptive survey design. The purpose of this design is to collect detailed and factual information that describes an existing phenomenon (Ezeani 1998). Population of the Study

The population of this study is made of employees of the three selected commercial banks that operate in Awka -Anambra State (First Bank,Fidelity Bank and Sterling Bank). The total population who were eligible to assist in filling -out the questionnaire is as follows:

\begin{tabular}{|l|l|c|}
\hline SN & Banks & Total Population \\
\hline 1 & First Bank, Aroma Branch, Awka & 25 \\
\hline 2 & Fidelity Bank PLC, Express way, Awka & 15 \\
\hline 3 & Sterling Bank Plc, Ziks Avenue, Awka & 20 \\
\hline & Total & $\mathbf{6 0}$ \\
\hline
\end{tabular}

Source: Field survey, 2015

\section{Sample Size}

Because of the smallness of the population, the researcher adopted complete enumeration.

\section{Sources of Data Collection}

The source of data for this study was primary source. The Primary data used was questionnaire. The questionnaire was structured and the respondents were placed on a five point likert scale.

The scale ranges from (5) strongly Agree (SA), Agree (A) (4) undecided (U) (3) Disagree (D) (2) Strongly Disagree (SD) (1).

\section{Validity of Instrument}

The questionnaire was designed in simple language to avoid ambiguity of questions and was structured in line with the objectives of the study. The study adopted Content Validity to validate the research instrument.

\section{Reliability of Instrument}

This was done using Test Re-Test with 15 copies of questionnaire.

\begin{tabular}{|c|c|c|c|c|}
\hline $\mathbf{S} / \mathbf{N}$ & Pre-test responses $\mathbf{x})$ & $\begin{array}{c}\text { Post-test } \\
\text { responses (y) }\end{array}$ & $\begin{array}{c}\mathbf{d i} \\
\mathbf{( x - y )}\end{array}$ & $\mathbf{d i}^{2}$ \\
\hline 1 & 10 & 9 & 1 & 1 \\
\hline 2 & 12 & 13 & -1 & 1 \\
\hline 3 & 15 & 12 & 3 & 0 \\
\hline 4 & 13 & 13 & -1 & 1 \\
\hline 5 & 14 & 15 & 2 & 4 \\
\hline 6 & 15 & 13 & 3 & 9 \\
\hline 7 & 12 & 9 & 0 & 0 \\
\hline 8 & 10 & 10 & 12 & 4 \\
\hline 9 & 12 & 14 & 2 & 4 \\
\hline 10 & 15 & 13 & & 33 \\
\hline
\end{tabular}

Source: Field Survey, 2015 
Formula for the test re-test is

$$
\begin{aligned}
& 1-\frac{6 \sum \mathrm{di}^{2}}{2} \text {. } \\
& \mathrm{n}\left(\mathrm{n}^{\left.\frac{2}{2}-1\right)}\right. \\
& 1-\underline{6(33)} \\
& 10\left(10^{2}-1\right) \\
& 1-\frac{198}{10(99)} \\
& \text { Where } \\
& 1=\text { no of test done } \\
& 6=\text { constant } \\
& \sum \mathrm{di}^{2}=\quad \text { total no of di2 } \\
& \mathrm{n}=\text { total no of questionnaire } \\
& 1-\frac{198}{990} \text {. } \\
& 1-0.2 \\
& =0.8
\end{aligned}
$$

From the reliability test, a figure of 0.8 was obtained which show the instrument is highly reliable.

\section{Method of Data Analysis}

The data was analysed in line with the research question and hypothesis. The Pearson's Product Moment Correlation Coefficient was used to test the hypothesis using SPSS Version 20.

\section{DATA ANALYSIS}

Out of the 56 respondents, 22 employees had worked within the banking sector for a period of 1 to 3 years representing 39.3\%. 36\% for a period of between 4 and 6 years; while $25 \%$ had been in service for over 6 years. It shows that $52 \%$ of the respondents had worked in different banks before joining one of these banks while $48 \%$ of employees is working at the same bank but are willing to leave if they find a better offer from another bank.

\section{HYPOTHESIS TESTING}

Ho: There is no significant relationship between employees salary and employee satisfaction. $\mathbf{H}_{1}$ : There is a significant relationship between employees salary and employee satisfaction.

Table 1: Descriptive Statistics

\begin{tabular}{|l|l|l|r|}
\hline & Mean & Std. Deviation & $\mathrm{N}$ \\
\hline Salary & 4.1857 & 0.88944 & 56 \\
$\begin{array}{l}\text { Employee } \\
\text { satisfaction }\end{array}$ & 3.6429 & & 56 \\
\end{tabular}

Source: Field survey and analysis SPSS, 2015 
Table 2: Correlations

\begin{tabular}{|c|cc|c|}
\hline & Salary & $\begin{array}{l}\text { employee } \\
\text { satisfaction }\end{array}$ \\
\hline Salary Pearson Correlation & & 1 & 0.339 \\
Sig. (2-tailed) & & 0.004 \\
$\mathrm{~N}$ & 56 & 56 \\
\hline $\begin{array}{l}\text { Employee satisfaction Pearson } \\
\text { Correlation Sig. (2-tailed) }\end{array}$ & 0.339 & & 56 \\
$\mathrm{~N}$ & 0.004 & & \\
\hline
\end{tabular}

Correlation is Significant at 0.01 level (2-tail)

Source: Field survey and analysis SPSS ver. 20, 2015

The $r$ value indicates that there exists a relationship between the two variables, but a weak relationship. The calculated $r$ value is 0.339 with a significance of 0.004 . This indicates that there is significant correlation between the variables. Therefore, reject we the null hypothesis and state that there is a weak positive relationship between employee salary and employee satisfaction (if there is an increase in salary, then satisfaction will also increase but the increase will be minor).

\section{Summary of Finding}

SUMMARY OF FINDING, CONCLUSION AND RECOMMENDATIONS

After the analysis of collected data, it was found that the value of the Pearson Product Moment Correlation is at 0.34 . This indicates that there is a positive weak relationship between salary and employee satisfaction. It further revealed that salary alone without other incentives like bonuses, job security, regular promotion, etc cannot make employee satisfied; employee satisfaction increases as salary increase but sluggishly.

\section{Discussion of Finding}

The study discovered that there is a weak relationship between salary and employee satisfaction in selected banks in Anambra; Awka metropolis precisely but positive. This agreed with what Mwakidimi and Obwogi (2015) observed that pay has a weak influence on employee retention while work environment had a strongest influence. Also Adeoye and Ziska (2014) found a weak significant correlation between compensation management and employee job satisfaction. Mensah (2012) also support these when he observed that though management implements some of the compensation available, there are other benefits which are not satisfactorily administered and this has contributed to lack of zeal towards work (dissatisfaction).

\section{CONCLUSION}

In view of the above findings, the study concludes that, to prevent employee mobility; banking industry should formulate, administer and implement a good compensation policies that would allow them retain their talented employee. When employees are satisfied, they stay long with the organisation. The incremental growth in banking industry is slow and not many people are willing to wait long when other banks are offering better initial as well as incremental packages. It therefore implies that First bank, Fidelity and Sterling banks should review their compensation package to attract, retain and motivate the talent pool. 


\section{RECOMMENDATIONS}

In line with this study, the following recommendations were made:

* The banks while framing their compensation policies should not only target salary but other things like work environments.

* The compensation structure should include new and enticing ways to retain and motivate employees with a wide range of benefit designed to enhance individual effort. For instance, banks may use various methods to support education of its employees.

* Commercial banks should also introduce generous benefits like post-retirement medical treatment, regular promotion, job security etc as a tool for retaining talent.

\section{References}

Adams, J.S. (1963). Toward an understanding of inequity. Journal of Abnormal Psychology, 67, 422-436.

Adeoye, A. O. \&Ziska, F. (2014). Compensation management and employee job satisfaction.

Alsabri, M. A. \& Ramesh, H. N. (2012) "Impact of Employees Motivation on Banking Effectiveness - A study of selected banks in Shimoga city India”, International Journal of Research in Computer Application \& Management, II(7), p61,

Armstrong M (2003). A Handbook of Human Resource Management Practice, 9 th Edition. Great Britain, Aberystwyth, Wales: Cambrian Printers Ltd.

Azash S, Safari R, Thirupalu N, \&Subhan, B. (2012).Job Characteristics as Predictors of Work Motivation and Job Satisfaction of Bank Employees.International Journal of Business and Management Tomorrow, 2(1): 1-7

Bartlett C, Ghoshal S (2013).Building Competitive Advantage through people.MIT Sloan Management Review, 43(2): 34-41.

Bashaw, E. R., \& Grant, S. E. (1994).Exploring the Distinctive Nature of Work Commitments: their relationships with personal characteristics, job performance and the propensity to leave.Journal of personal selling and sales management, 14(2), 41-56.

Benita, C. C. \&Anghelache, V. (2012).Teacher Motivation and Satisfaction for Professional Activity.Social and Behavioural Science, 33: 563-567.

Bowen, D. E. \& Lawler, E. (1995).Empowering Service Employees. Sloan Management Review, Summer, 73-84

Curtis, S., \& Wright, D. (2001).Retaining Employees-the Fast Track to Commitment. Management Research News, 24(8), 59-64.

David, M. M. \&Obwogi, J. (2015). “Effects of Pay and Work Environment of Employee Retention”

DeCenzo, D. A. \& Robbins, S. P. (2005).Fundamentals of Human Resource Management

Demming, W. E. (1986). Out of the Crisis. Cambridge, MA: MIT Institute for Advanced Engineering Study.

Dessler, G. (2008). Human Resource Management. USA: Prenctice Hall.

Encinosa III W. E., Gaynor M, \&Rebitzer, J. B. (2007).Thesociology of groups and economics of incentives: theory and evidence on compensation systems. Journal of Economic Behaviour and Organization,62(2): 187-214.

Encinosa III W.E., Gaynor, M. \&Rebitzer, J.B. (2007). Thesociology of groups and economics of incentives: theory and evidence on compensation systems. Journal of Economic Behaviour and Organisation, 62(2): 187-214.

Falola, H. O. (2014). Incentives packages and employees' attitudes to work: a study of selected government parastatals in Ogun State, South-West, Nigeria, International Journal of Research in Business and Social Science IJRBS, 2014, 3(1), p. 2147-4478.

Financial Results/ part 2, (2013): Nigeria's Top Banks - how they rank, articles. Accessed 5 $5^{\text {th }}$ October, 2015.

Gardner, D. G., Dyne, L.V. \& Pierce J. L. (2004). The Effects of Pay Level on Organization-based Self-Esteem and Performance: A field study. Journal of Occupational and Organisational Psychology, 77(3): 307-322.

Heneman, R. L. (1992). Merit Pay: Linking Pay Increasesto Performance Ratings. MA, US: Addison-Wesley/Addison Wesley Longman

Heneman. R. L. (1992). Merit Pay: Linking Pay Increases to Performance Ratings. MA, US: Addison-Wesley/Addison Wesley Longman 
Chiekezie, O. M., Emejulu, G., \& Nwanneka, A. (2017). Compensation Management And Employee Retention Of Selected Commercial Banks In Anambra State, Nigeria. Archives of Business Research, 5(3), 115-127

Herzberg, F. (1966).Work and the Nature of Man. Clevelland: World.

Horwitz, F. (2010).Retention strategies critical in a global market skills shortage.Available online at http://www.gsb.uct.ac.za/hrm.Accessed on 21 September 2015.

Hytter, A. (2007). Retention Strategies in France and Sweden. The Irish Journal of Management, 28(1), 59-79.

Idemobi, E. I., Onyeizugbe, C. U. \&Akpunonu, E. O.(2011).Compensation Management as tool for improving Organizational Performance in the Public Sectors: Astudy of the Civil Service of Anambra State of Nigeria.Sacha Journal of Policy and Strategic Studies

Jyothi, P. \&Venkatesh,N.D. (2006). Human Resource Management. New Delhi: Oxford University Press.

Kaliprasad, M. (2006). The Human Factor I: Attracting, Retaining, and Motivating Capable People. Cost Engineering, 48(6), 20-26.

Kaplan, R. S. \& Norton, D. P. (2007).Using the Balanced Scorecard as a Strategic Management System.Harvard Business Review, July-August: 1-15.

Khan, W.\& O. Mufti, (2012). "Effect of Compensation on Motivating Employees in Public and Private Banks of Peshawar", Journal of Basic and Applied Scientific Research, II(5),

Kuvaas, B. (2006). Work Performance, Affective Commitment, and Work Motivation: The Roles of Pay Administration and Pay Level. Journal of OrganisationalBehaviour, 27: 365-385.

Lauri, Y., Morgan, M., Dave, E, \& Broman M. (2014).The Tenuous Relationship Between Salary and Satisfaction. Journal of behavioural studies in business vol. 7

Lawler III, E. E. (2003). Reward Practices and Performance Management System Effectiveness. A Paper Delivered at Centre for Effective Organisations, Marshall School of Business, University of Southern California, Los Angeles, California, USA, July 8, pp. 1-19.

Lee, C. H. \&Bruvold, N. T. (2003).Creating Value for Employees: Investment in Employee Development.International Journal of Human Resource Management, 14(6): 981-1000.

Lepak, D.P. \& Snell, S. A. (2002).Examining the Human Resource architecture: The Relationships among Human Capital, Employment and Human Resource Configurations.Journal of Management, 28(4): 517-543

Mwakidimi, D. M. \&Obwogi, J. (2015).Effect of Pay and Work Environment on Employee Retention.

Nazim-ud-Din M (2013). HR Practices in Insurance Companies: A case study of Bangladesh. Abasyn Journal of Social Sciences, 6(2): 77-90.

Newstrom, John W. (2009). Organizational Behaviour: Human Behaviour at Work (Twelfth Edition). New Delhi: Tata McGraw Hill Education Private limited.

Obisi, C. (2003). Organizational behaviour; concepts and applications, Malthouse Press.

Octavious (ND) "Complete details on Payroll, Salary and Compensation - Organizational Effectiveness" www.citehr.com/99840. Accessed 27th August, 2015

Okpara, J. (2004). The Impact of Salary differential on Managerial Job Satisfaction: a study of the Gender gap and its implication foe education and practice.

Oshagbemi T., Gender Differences in the Job Satisfaction of University Teachers, Women in Management Review, 2000, 15, p. 331-343.

Osibanjo, A.0. (2012) Executive Perception of the Impact of Flexitime on Organizational performamce: evidence from the Nigeria Private Sector, International Journal of Applied Behavioural Economics, IJABE, 2012, 1(3), p. 1627.

Petera, P. (2011). Evaluating the Quality of Rewards Systems.European Financial and Accounting Journal, 6(3): 6691.

Shieh, C. J. (2008). Effect of Corporate Compensation Design on Organisational Performance.Social Behaviour and Personality, 36(6): 827-840.

Smith, P.C. (1992), "In Pursuit of Happiness: Why Study General Job Satisfaction?," in C.J Cranny, P.C. Smith \& E. F. Stone (eds.), Job Satisfaction 5-19, New York: Lexington Books.

Snell, S.A. \& Dean, J. W. Jr. (1994).Strategic Compensation for Integrated Manufacturing: The Moderating Effects of Job and Organisational inertia.Academy of Management Journal, 37: 1109-1140. 
Terera, S. R. \&Ngirande, H. (2014).The impact of Rewards on Job Satisfaction and Employee Retention.Mediterranean Journal of Social Sciences, 5(1): 481-487.

Van der Merwe, S. P. (2009). Determinants of Family Employee Work Performance and Compensation in Family Business.South African Journal of Business Management, 40(1): 51-63.

Van der Merwe, S. P. (2009). Determinants of family employee work performance and compensation in family business. South African Journal of Business Management, 40(1): 51-63. www.fidelitybanknigeria.com/about-us. Accessed October 5, 2015 www.firstbanknigeria.com/about-us. Accessed October 5, 2015 www.sterlingbanknigeria.com/about-us. Accessed October 5, 2015

Zingheim, P. \& Schuster, J. (2007).The next decade for pay and rewards. Compensation and Benefits Review, 37(1), 26-32. 